\title{
The rise and fall of the Canadian pulp and paper sector
}

\author{
by Bryan E.C. Bogdanski
}

\begin{abstract}
The Canadian pulp and paper sector grew from a newsprint production centre to feed the United States newspaper industry to become one of the most significant pulp and paper manufacturing centres in the world, especially in mechanical pulp and paper products. Despite its size it has never broken completely free from its U.S. roots. Recent changes in the U.S. markets, coupled with trade globalization, and increased competition from other producing regions have led to significant change in the Canadian sector since 2000. Looking out over the next ten years, trends are expected to persist and present numerous challenges to the Canadian pulp and paper products industries and dependent industries.
\end{abstract}

Keywords: paper products, pulp, history, outlook, Canada

\section{RÉSUMÉ}

Le secteur canadien des pâtes et papiers a connu une croissance qui la fait passer de centre de production de papier journal destiné à alimenter les journaux des États-Unis pour devenir l'un des centres les plus importants de production de pâte et de papier du monde, notamment dans les produits de pâte mécanique et de papier. Malgré son importance, il nảa jamais été en mesure de sasservir de ses racines américaines. Les récents changements dans le marché américain, parallèlement avec la mondialisation des marchés et la compétition accrue des autres régions productrices, ont entrainé depuis 2000 une mutation profonde dans ce secteur au Canada depuis 2000. Au cours des dix prochaines années, on prévoit que les tendances se maintiendront et poseront de nombreux défis aux entreprises canadiennes des produits de pâte et papier et aux industries qui en dépendent.

Mots clés : produits de papier, pâte, histoire, perspective, Canada

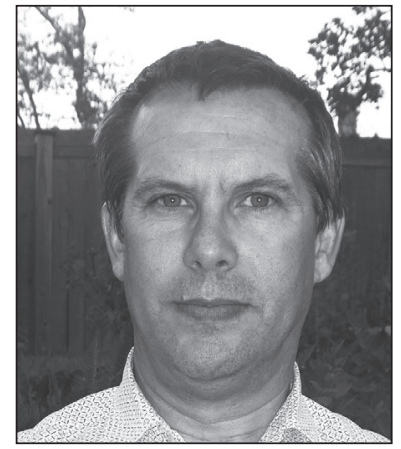

Bryan E.C. Bogdanski

\section{Introduction}

Over the last century Canada became one of the largest pulp and paper production centres of the world and arguably the world's most significant exporter of these products. This development was due to several natural advantages in the production of pulp and paper. These advantages included possessing abundant timber, water, and energy resources and geographical proximity to a growing market in the United States (U.S.).

During the past decade the Canadian sector has faced decreasing North American paper demand, expansion of pulp and paper capacity in other countries, and an increased role of recovered paper in global paper production. All of these trends eroded Canada's comparative and competitive advantages it historically enjoyed. The question now is where will the sector go from here?

In this paper I look at the history of the sector to understand how its current structure came to be. Then I describe recent trends and consider the sector's future over the next ten years.

\section{Early Beginnings}

The origins of the Canadian paper industry did not start with wood but instead with fabric. The first rag-based paper mill in Canada was established in 1803 in St. Andrews, Quebec to produce paper for local consumption (Roach 1994). The woodbased pulp and paper industry did not get going for another 60 years, some 20 years after Nova Scotian Charles Fenerty first made paper from wood pulp (Snider 1990). In 1866 the first groundwood (mechanical) pulp mill was established in Valleyfield, Quebec by Alexander Buntin and the first chemical wood pulp mill was opened at Windsor Mills in Quebec by Angus Logan and Company in the same year (Dominion Bureau of Statistics 1930). The industry expanded outside of Quebec and into Ontario in 1887 where the first sulphite pulp mill was built at Merritton, Ontario by Charles Riordon (Dominion Bureau of Statistics 1930). Soon afterward, the industry expanded outside the provinces of Quebec and Ontario. In 1887 a sulphite mill was established in Saint John, New Brunswick and in 1897 a small sulphite mill was established at Black River in Newfoundland (Wallace 1949). The industry eventually expanded to Western Canada with the establishment of a pulp mill in Swanson Bay, British Columbia (BC) in 1903 (Christie 2004).

\section{Industry Take-off: 1900-1945}

The Canadian paper industry grew rapidly after 1900 due to huge increased demand for newsprint in the United States (Fig. 1 and Fig. 2). Demand for newsprint in the United States was 


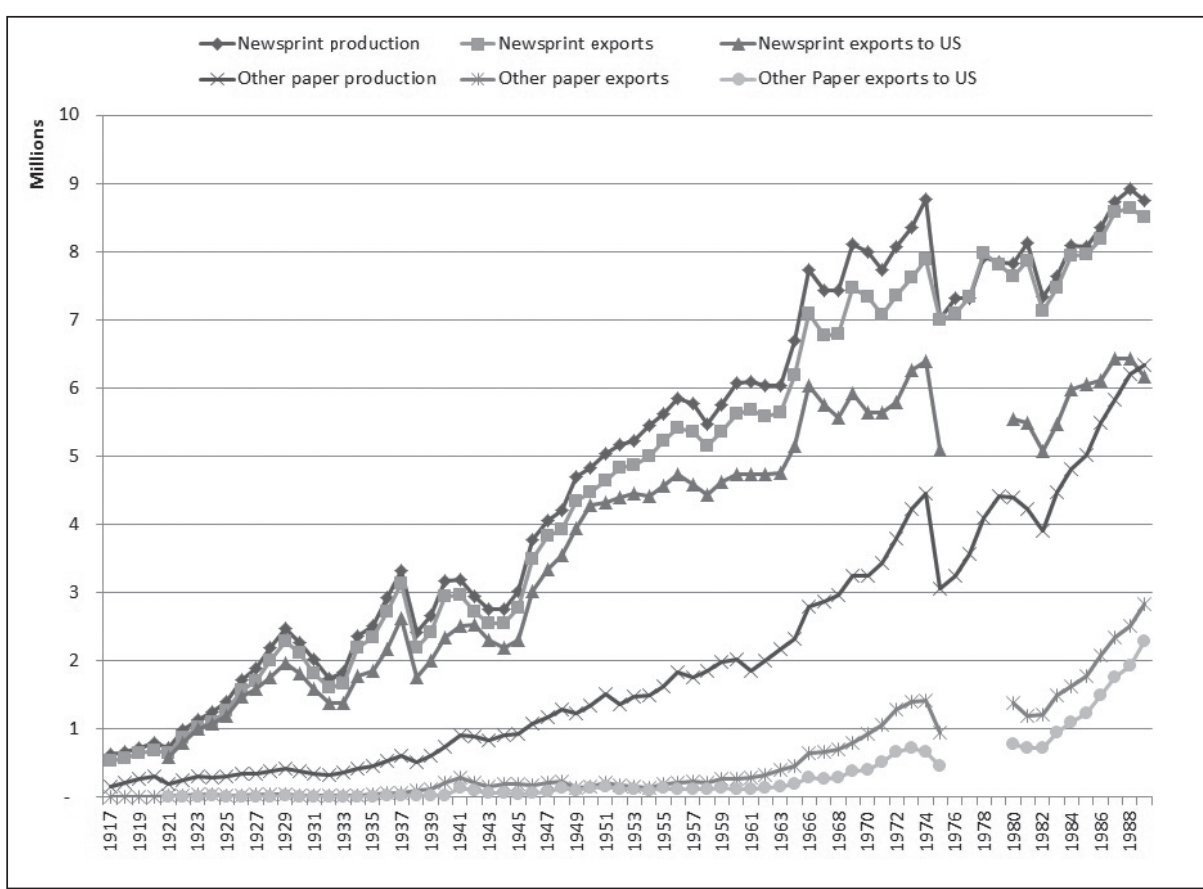

Fig. 1. Canadian paper production and exports, 1917 to 1989 (tonnes). Sources: Statistics Canada 1983, NRCan 2001.

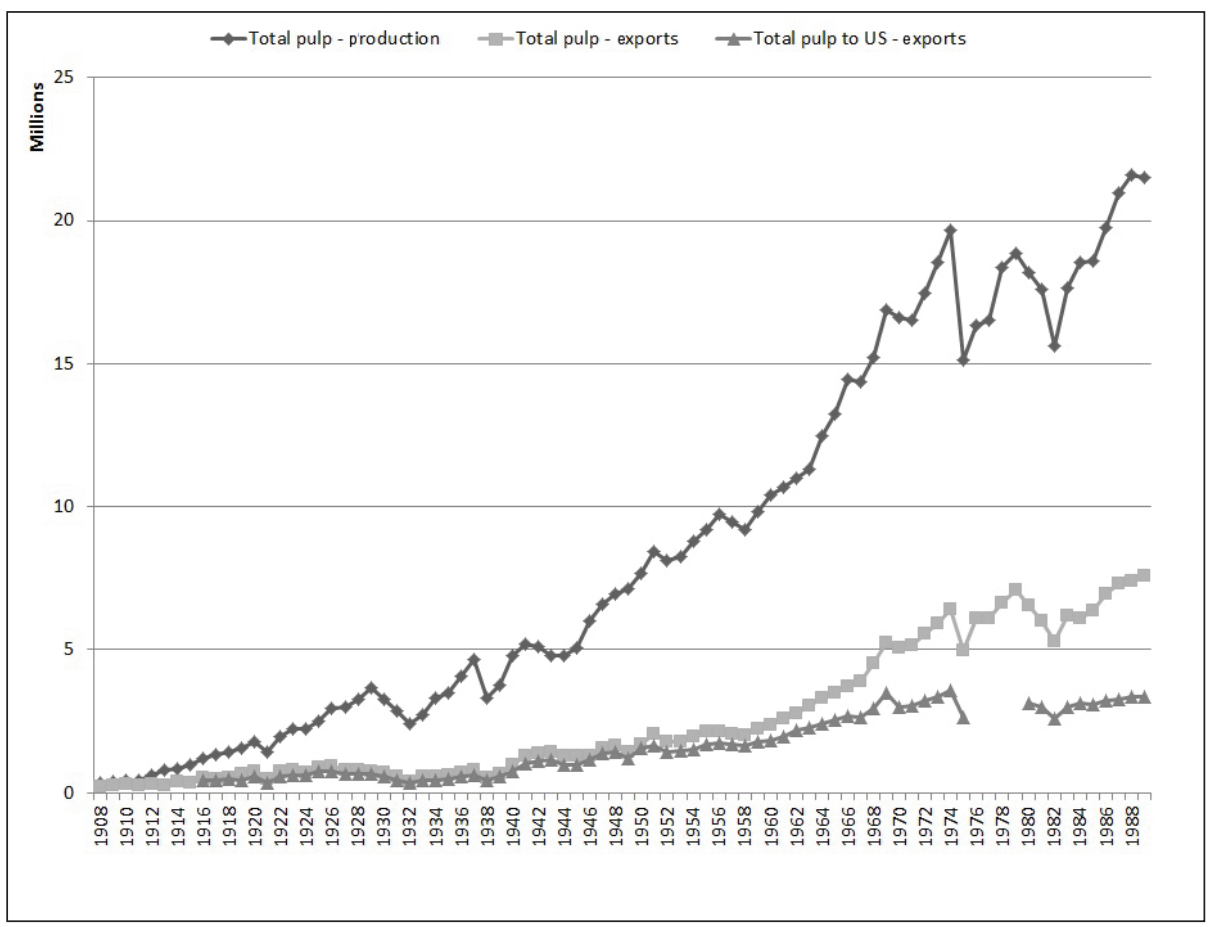

Fig. 2. Historical Canadian pulp production and exports, 1908 to 1989 (tonnes). Sources: Statistics Canada 1983, NRCan 2001, FAO n.d.

driven by increasing population, increasing wealth, and the use of print advertising for product marketing. Consumption of newsprint was further spurred on by lower newsprint costs due to the mechanization of mechanical and chemical pulp making (Roach 1994). The huge increase in newsprint demand could not be met by U.S. supply alone, and with dwindling supply of spruce pulpwood the industry shifted north to Canada. Spruce pulpwood was the preferred fibre supply for making mechanical wood pulp, the key ingredient in newsprint. In addition to an abundant supply of spruce pulpwood, Canada held abundant water resources. Canada's numerous rivers provided a source of water for pulp manufacturing, an inexpensive transportation system for delivering pulpwood and for shipping out pulp or paper products, and a source of hydroelectric power (Shipley 1929). Moreover, U.S. tariffs on imported newsprint were reduced to zero from 20\% between 1909 and 1913 making Canada an attractive place for American industry investment (Toivanen 2004). The combination of abundant timber, water and energy and its close proximity to the largest U.S. markets led to tremendous growth of the industry.

Between 1908 and 1928 the industry grew from a few mills to 80 producing 3.6 million short tons of pulp and 2.8 million short tons of paper (Dominion Bureau of Statistics 1930). In $192856 \%$ of the wood pulp was produced in Quebec, 29\% in Ontario, 9\% in $\mathrm{BC}$, and $6 \%$ in the Maritime Provinces and Manitoba (Dominion Bureau of Statistics 1930). Globally, Canada was the third-largest exporter of wood pulp after Sweden and Norway (Dominion Bureau of Statistics 1930). While the pulp mills exported considerable amounts of production, the bulk of production, especially at mechanical pulp mills, was consumed in adjoining paper mills owned by the same company (CPPA 1966). Many Canadian mills were owned or financed by large U.S. newspaper companies and paper manufacturers (Roach 1994). In 1927, approximately $76 \%$ of the $\$ 525$ million of capital invested in the Canadian pulp and paper industry came from the United States (Shipley 1929). This was of no surprise since the U.S. imported about $90 \%$ of Canadian pulp and newsprint production at the time (Shipley 1929). 
The emerging industry consumed considerable resources. Pulpwood consumption in Canadian mills increased from 487 thousand cords (1.76 million cubic metres) of wood to 4.8 million cords (17.38 million cubic metres) between 1908 and 1928 (Dominion Bureau of Statistics 1930). A further 1.5 million cords (5.43 million cubic metres) of pulpwood was exported annually to the pulp industry in the Northeast region of the United States from private forest lands in Eastern Canada. Water and energy resources were also consumed in large quantities by the industry. By 1929 hydro power provided $90 \%$ of the power requirements of the pulp and paper industry accounting for $30 \%$ of the total water power developed in Canada (Roach 1994).

The industry expansion took a pause during World War II (Fig. 1 and Fig. 2). By 1940, Canadian industry was supplying $70 \%$ of the U.S. newsprint consumption and accounted for twothirds of the world's newsprint exports (Dominion Bureau of Statistics 1945). Newsprint accounted for $77 \%$ of total Canadian paper production in 1943, followed by paperboard, wrapping paper, book and writing paper, and tissue paper accounting for $14 \%, 4 \%, 3 \%$, and 2\%, respectively (Dominion Bureau of Statistics 1945). Pulp production reached over 5 million short tons of pulp, of which $62 \%$ was mechanical pulp and $28 \%$ was sulphite pulp. Though sulphate pulp was less than $10 \%$ of production at the time its production and use was increasing faster than other pulps (CPPA 1966).

\section{Post-war Growth: 1945-1990}

Growth of the Canadian paper industry continued steadily after the war, except for a 10-year period of stagnation between mid-1970 and mid-1980 (Fig. 1 and Fig. 2). However, North American newsprint demand growth for the first 10 years was met by increased capacity at existing mills. In 1957 a newsprint mill was constructed in British Columbia, the first Canadian newsprint mill built since before the war (Roach 1994). By 1950 Canada's share of the U.S. newsprint market reached its historic high of $80 \%$ (CPPA 1979). Although Canadian newsprint production continued to expand and shipments to the U.S. increased after 1950 U.S. supply increased faster and so Canadian market share began to decrease. One of the key reasons for this was a weakening of one of Canada's key advantages-its fibre advantage. The wider adoption of chemical sulphate (Kraft) pulping technology permitted the use of a greater variety of tree species, in particular pine trees and hardwoods in the Southern U.S. (Toivanen 2004). Consequently, over the coming years Canada's dominance in pulp and newsprint began to fade. By 1965 Canada's share of North American newsprint production fell to $72 \%$ (CPPA 1979) and to 57\% by 1990 (PPPC 2008a). Likewise, Canada's share of North American pulp production fell from $46 \%$ in 1937 to $35 \%$ in 1950 and then to $29 \%$ in 1990 (CPPA 1966, PPPC 2008b). One countertrend over this period was increased shipments to overseas markets. Overseas exports of newsprint increased from 200000 tonnes in 1950 to over 1.5 million tonnes in 1990 while overseas pulp shipments increased from less than 150000 tonnes to almost 4 million tonnes by 1990.

Two significant changes in the Canadian sector occurred after the World War II. One was the rise of chemical pulp manufacturing and the other was a modest diversification across products and markets. During the period of 1950 to 1990 there was significant growth of pulp and non-newsprint paper production. The rise of Kraft pulp manufacturing after the war redefined the Canadian industry. Between 1950 and 1990 the percentage of total Canadian pulp production made up of $\mathrm{Kraft}$ pulp increased from $12 \%$ to $45 \%$. Over this period the percentage of Kraft pulp exports to total pulp exports increased from $31 \%$ to $83 \%$. The emergence of increased demand in Asia and Europe for pulp was the main driving force behind the trends. Exports to Europe increased from just over 100000 tonnes in 1950 to over 2 million tonnes in 1990. Similarly exports to Asia went from virtually zero in 1950 to over 1.5 million tonnes in 1990 (CPPA 1986, 1999). The sum result was a broader market for Canadian market pulp products (Fig. 2).

Much of the new market pulp capacity was established in Western Canada, in areas with more resinous conifers or hardwoods. The rise of $\mathrm{BC}$ as a key pulp producer was in part due to the adoption of the Kraft processing technology that could use BC's abundant supply of pitchy pine species supplied primarily in the form of chips from BC's growing sawmilling sector. It was also due to expansion of industrial forestry into Northern BC, one of the last untapped supply areas of spruce in Canada (Wellwood 1960). In $192885 \%$ of pulp production was generated in Quebec (56\%) and Ontario (29\%) (Dominion Bureau of Statistics 1930). By 1980 Central Canada's percentage share dropped to $51 \%$, while British Columbias share increased to $29 \%$ of total production (NRCan 2001).

Increased pulp fibre supply in the form of chips was another trend during this period. Pulp fibre supply from sawmill chips and other residuals increased from 2\% in 1950 to $55 \%$ in 1990 (CPPA 1979, 1999). This trend reflected the increased integration and economic interdependence between the Canadian wood and paper sectors.

There were three other changes in the Canadian pulp industry over this period. One was the beginnings of the dissolving pulp industry, another was the beginnings of hybrid mechanical pulps (high yield pulps), and the third was the expanded use of recycled paper for papermaking. The development of a dissolving wood pulp industry in Canada began in the 1920s, initially to replace cotton linters in producing rayon and cellophane, but did not take off until the 1940s (Snider 1990). The industry grew steadily until the late 1960s before stalling for the next two decades (CPPA 1966, 1986). The other two changes occurred between 1970 and 1990. After major research breakthroughs in the 1950s and 1960s by Canadian scientists, production of high-yield pulps using a combination of chemicals or heat and mechanical treatment took off (Snider 1990). Between 1975 and 1990 production increased from 69000 tonnes to over 6 million tonnes, with exports increasing from zero to over 900000 tonnes (PPPC 2008b). Much of this new production capacity replaced older mechanical pulp capacity at integrated paper mills but some was focused on pulp markets. Lastly, use of recovered paper in papermaking increased after 1975. Between 1975 and early 1990 the percentage of furnish from recycled paper used in making paper in Canada increased from 5.6\% to $11.4 \%$ (CPPA 1999). A similar trend occurred in the U.S. (Howard 2007). The increased use of recovered paper in North America decreased the need for new pulp capacity to meet growing paper demands (Diesen 1998).

There were some impressive changes in the paper sector over this period. There was significant growth in printing and writing paper and containerboard production, though not at the same time. Containerboard production expansion occurred 
mainly between 1950 and 1975 and the majority of the increased production was for domestic use. Printing and writing paper production took off after 1970 with sustained growth through to 1990 . Between 1960 and 1990 printing and writing paper production increased about 366000 tonnes to over 3.6 million tonnes in 1990 (CPPA 1966, 1999). And unlike containerboard, the vast majority $(79 \%)$ of the increased production was destined for export markets (CPPA 1999). The majority of the increased production was composed of uncoated mechanical papers destined for U.S. markets. These papers are used extensively in advertising inserts, flyers, catalogues, directories, and some magazines (Jaakko Pöyry 1995). There was also expansion of uncoated woodfree (made from Kraft pulp) paper production and some coated mechanical papers (CPPA 1999). But most of this production was to meet domestic demand. These papers are used for office reprographics and in the production of magazines and commercial printing products and other highquality printing products (Jaakko Pöyry 1995). The majority of the production increase occurred in Central Canada, the largest domestic market in close distance to large, concentrated U.S. population centres.

\section{The Golden Decade: 1990s}

The Canadian paper industry reached new heights in the 1990 s and many of the trends over the previous few decades continued against the backdrop of the U.S.Canada bilateral trade agreement (1989), the North American Free Trade Agreement (1994), and the General Agreement on Tariffs and Trade (GATT) Uruguay Round multilateral trade agreement (1995) (Fig. 3 and Fig. 4). The Canadian newsprint industry peaked in 1988 and throughout the 1990s production remained around 9 million tonnes despite softening North American demand and increasing U.S. production. This was accomplished by increased shipments to overseas markets. While newsprint demand and production began to wane, Canadian production of other printing and writing papers n.d. [f].

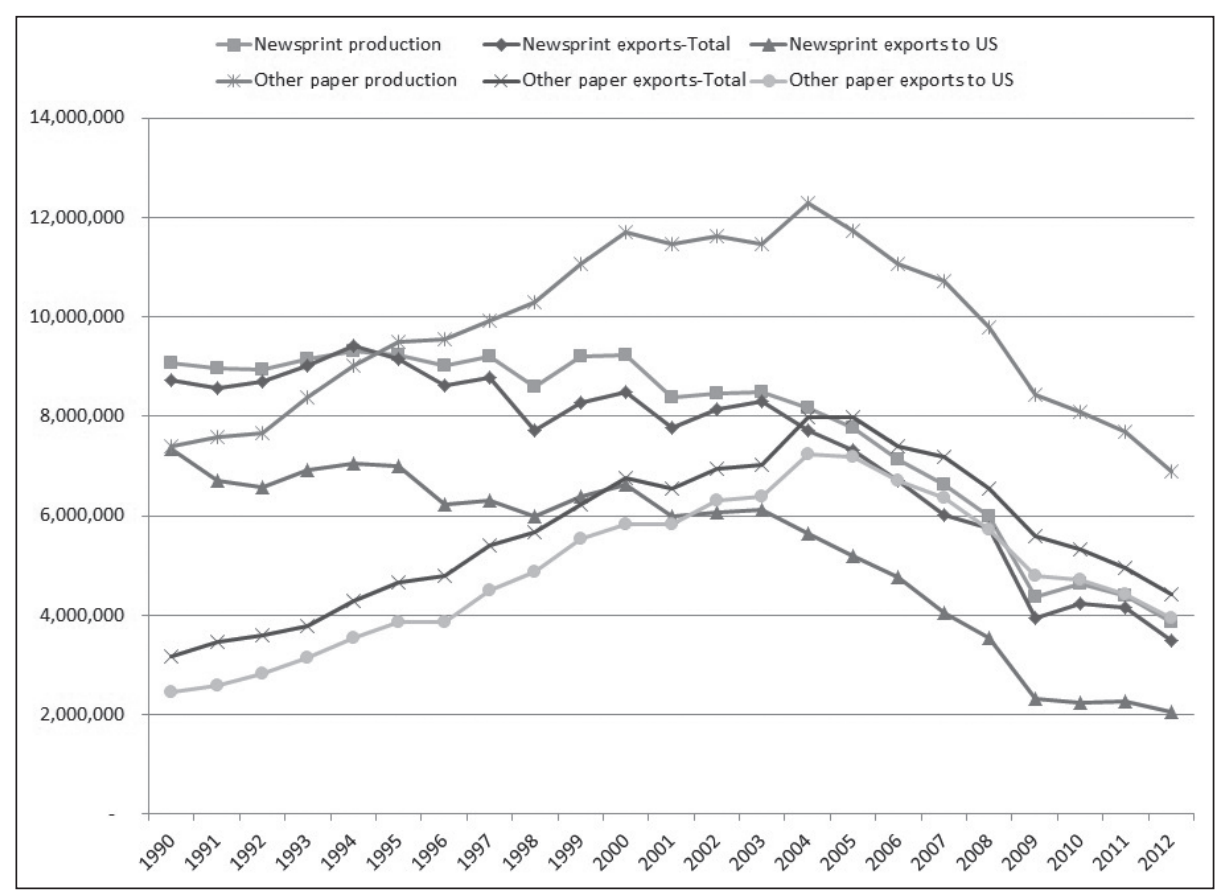

Fig. 3. Canadian production and exports of newsprint and other paper products, 1990 to 2012 (tonnes). Sources: FAO n.d. and Statistics Canada n.d. [f]. Excludes converted paper products.

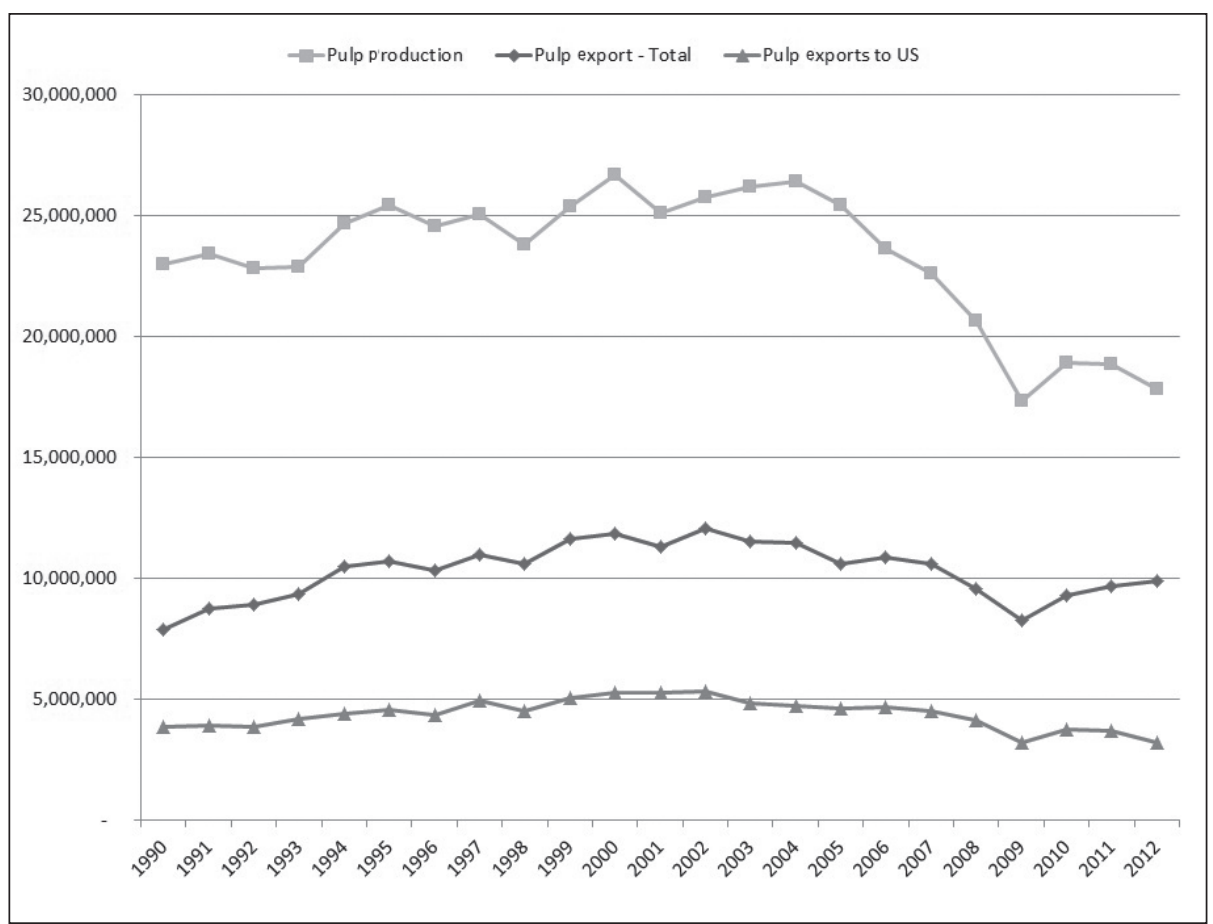

Fig. 4. Canadian production and exports of pulp, 1990 to 2012 (tonnes). Sources: FAO n.d. and Statistics Canada

continued to increase, driven by increasing domestic and U.S. demand (Fig. 3 and Fig. 4). Most of the increased production consisted of uncoated and coated mechanical papers, though there was also a modest increase in uncoated woodfree papers (CPPA 1999). The increased demand for mechanical papers was driven by demand for directories, catalogues, magazines, 
newspaper advertising inserts, and books. The high growth in demand during this period led leading industry analysts at Woodbridge, Reed and Associates (1988) and Jaakko Pöyry (1995) to predict continued expansion out to 2010, even for newsprint, in spite of concerns the digitization of many types of communications media and expanding environmental policies could dampen demand for paper. Production of other types of paper such as sanitary papers and wrapping and packaging papers increased modestly throughout the 1990s. Containerboard and boxboard production increased substantially with most of the increased production sent to foreign markets (CPPA 1999). Unlike some other paper products, paperboard products were shipped to a diverse group of countries in Europe, Latin America and Asia, and not just the U.S. market (CPPA 1999).

Converted paper industries flourished over the decade. The value of converted paper production shipments (in nominal dollars) increased 56\% between 1990 and 1999 compared to $29 \%$ growth for the pulp, paper, and paperboard industries (Statistics Canada n.d. [b]). The fastest-growing segments of the sector were sanitary paper products, coated paper and paper bags, and paperboard containers. Also, the converted paper industries saw an increase in total number of employees of $17 \%$ compared to a decrease of $22 \%$ for the primary paper industries. In addition, exports of converted products (Harmonised System products HS 4811 to HS 4823) increased $331 \%$ compared to $55 \%$ for primary (bulk) paper products and $23 \%$ for pulp exports (Statistics Canada n.d. [e]). By the end of the decade, the value of exports as a share of total converted paper shipment value reached 36\%, up from $13 \%$ (Statistics Canada n.d. [b],[e]).

A rise in imports was another trend during the 1990s. In particular, there was an increase in imports of various types of wrapping and packaging paper and paperboard and

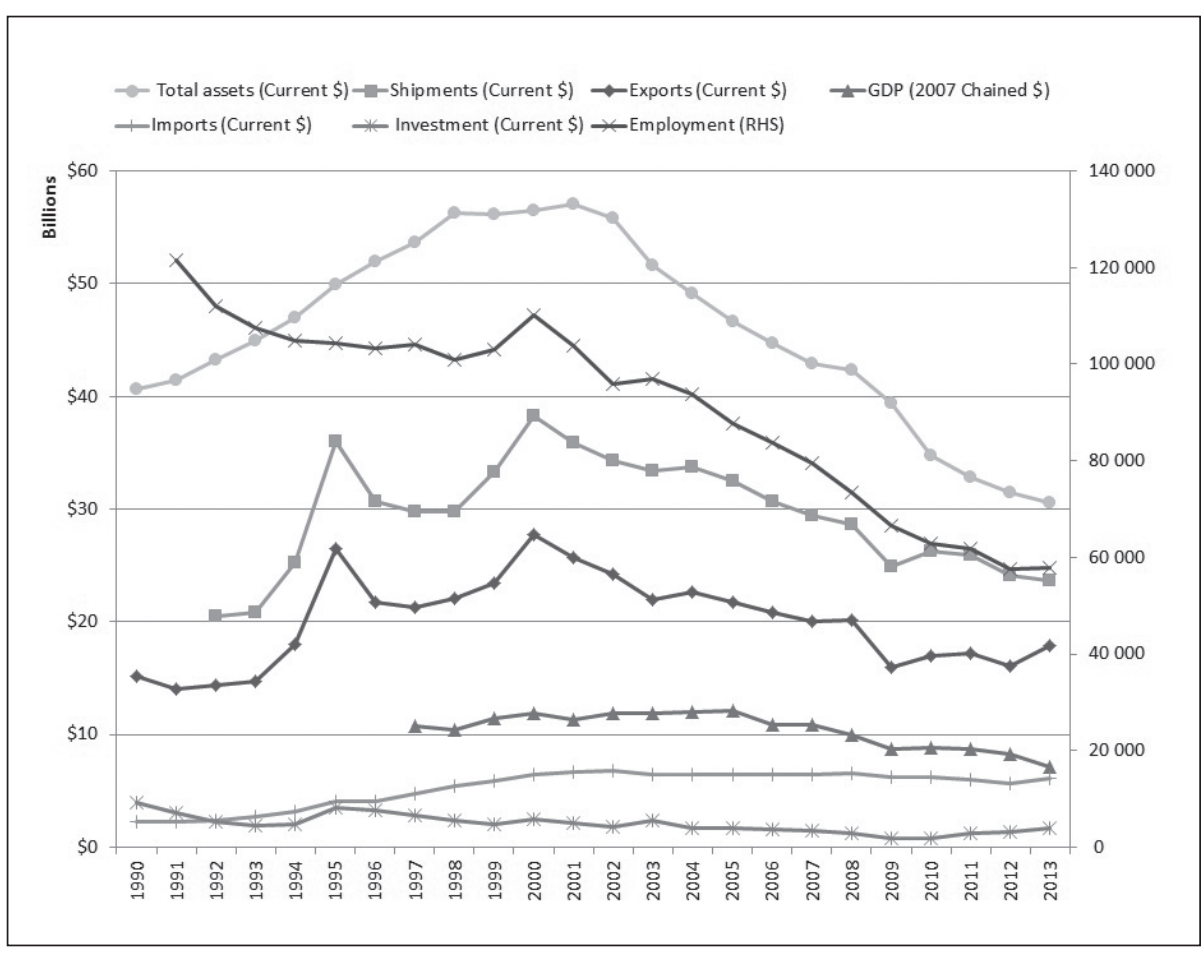

Fig. 5. Principal paper sector statistics, 1990 to 2013 (estimates). Sources: Statistics Canada n.d. [a],[b],[c],[d],[f]. printing and writing papers. Uncoated and coated printing and writing paper imports increased considerably but converted product imports grew faster $(233 \%)$ than bulk paper imports over this period (150\%). The majority of the increased paper imports were received in Ontario but all provinces saw increased imports over the decade, with the vast majority of the imports (90\%) from the United States.

Pulp production and exports expanded during the 1990s but there were some notable shifts in the trends (Fig. 3 and Fig. 4). Chemical pulp production and exports expanded rapidly over the first five years of the decade but then changed little over the last five years (PPPC 2008b). Recycled fibre utilization for paper and paperboard production increased considerably in Canada and the U.S. during this time, perhaps partly explaining the tempered growth in pulp production and exports. Utilization of recycled fibre by Canadian paper manufacturers more than doubled from $11.4 \%$ to over 25\% (CPPA 1999), while it increased from 25\% to 35\% in the United States (Howard 2007).

Finally, the 1990s was a decade that saw significant reductions of pulp and paper manufacturing pollution, addressing many of the long-standing public concerns surrounding the environmental impact of the industry. As measured on a pertonne basis relative to 1990 , there were significant reductions in chlorine use $(77 \%)$, water use $(27 \%)$, biochemical oxygen demand (91\%), total suspended solids in effluent (67\%), and organochlorines (78\%) by 1997 (CPPA 1999). Also, there was complete elimination of dioxin and furan releases by 1995. In total, between 1990 and 1997, the sector expended over five billion dollars on pollution abatement activities (CPPA 1999).

\section{Fall From The Top}

The new millennium brought significant change to the Canadian paper sector (Fig. 3 and Fig. 4). All aggregate measures of sector size such as value of shipments, value of exports, employment, gross domestic product, asset value, and capital expenditures trended down over the 2000s (Fig. 5). Part of the change was due to the brief 2001 U.S. recession and the severe global recession of 2007 to 2009, but part was due to fundamental changes in North American paper consumption (Fig. 6), especially an abrupt change in demand for graphic papers due to competition from digital media, paper conservation actions by businesses and consumers, and changes in reading habits (Hetemäki 2010).

The most significant decline, in terms of physical production, value and capacity, occurred in the newsprint industry. The U.S. newspaper industry, the original raison dềtre of the Canadian pulp and paper sector, has been the key driver behind this downward trend. Though production levels stagnated and exports began to 
decline at the end of the 1990s, large, successive export demand declines did not begin to occur until 2000, driven almost entirely by decreased U.S. consumption. The greatest single drop occurred during the great recession (20072009), with export volumes dropping over 2 million tonnes, equal to the cumulative decrease over the previous seven years. To put this into perspective, the loss of 4.8 million tonnes of newsprint demand over the decade was equivalent to the loss of about fifteen newsprint mills employing thousands of workers.

The next biggest change was North American consumption of uncoated mechanical writing and printing papers. Unlike newsprint, consumption of these papers increased steadily between 2000 and 2007 before falling significantly during the recession. By the end of the decade, the 800-thousand-tonne increase in consumption was wiped out by a 1.5-million-tonne decrease during the recession. Unfortunately, the demand for Canadian uncoated mechanical papers continued to fall during 2010 to 2013, but with export demand stabilizing somewhat in 2013. The reduced demand on Canadian mills was led by decreased U.S. demand for printed materials such as novels, magazines, and newspaper inserts.

Uncoated woodfree writing and printing papers, also known as business papers, followed a similar trend to newsprint during the decade. North American demand peaked in 1999 (14 million tonnes) and continued to fall throughout the decade, with significant drops in demand in 2001 and then again during the 2007-2009 recession. Although Canadian production was oneeighth that of the U.S. at the beginning of the decade, declining U.S. demand did not significantly affect the Canadian industry until after 2005. Between 2005 and 2009 Canadian production fell by one-half and exports fell by two-thirds. As U.S. demand continued to decline over the decade, U.S. import demand began to fall and exports began to increase. By the end of the decade the U.S. industry's market share of the shrinking North American market had expanded at the expense of Canadian producers, leaving Canadian production one-twelfth of U.S. production.

Coated writing and printing papers followed a slightly different trend over the decade. North American consumption grew from 2000 to 2004 before decreasing every year hence, with a large drop-off during the recession. Aggregate coated paper demand declined over 30\% during the recession. The impact on Canadian producers was commensurate with the drop in demand, though the impact on coated woodfree printing and writing paper exports, with volumes already much smaller than coated mechanical papers, was much greater. Between 2005 and 2009 Canadian coated woodfree exports declined over $90 \%$ from around 310000 tonnes to 24000 tonnes. The decline in coated mechanical papers was less but still significant with a decline of around 55\%, from 785000 tonnes to 354000 tonnes. Similar to uncoated woodfree papers, Canadian share of the U.S. and North American market declined considerably. Also, Canada became a net importer of coated papers in terms of volume and value. Specifically, Canada became a larger net importer of coated woodfree papers and a smaller net exporter of coated mechanical papers.

North American wrapping and packaging paper and paperboard consumption stagnated over the years before the 2007-2009 recession, at which point consumption plunged about $15 \%$. Prior to the 2000 s the paper class generally followed the ebbs and flows of the general North American economy (Paperloop.com 2000) but during the decade consumption stayed flat despite growing U.S. and Canadian economies, indicative of offshoring of manufacturing, packaging, and general consumer trends. Canadian production and exports fared poorly over the decade. Canadian production peaked in 2000 and declined year-over-year through the decade before plunging about 20\% during the recession. Canadian exports followed a similar declining pattern, though the major driver was declining domestic consumption. Canadian consumption contributed $60 \%$ to the decline in Canadian production over the decade. Canadian production trends contrast with U.S. production and exports, which increased year-over-year before abruptly falling during the recession.

North American consumption of converted papers increased considerably through the years leading up to the recession, especially in the United States. Between 2000 and 2007 consumption increased by $\$ 12.5$ billion U.S. But consumption declined $\$ 10.5$ billion U.S. during the recession (U.S. Census n.d., U.S. ITC n.d.). For Canada, even before the recession, 
industry sales and exports were on the decline and by the time the recession occurred Canadian sales and exports fell further while imports stayed constant(Statistics Canada n.d. [b],[e]). The decline in value was more to do with a decreased CanadaU.S. dollar exchange rate than a decrease in volume of exports. While there is incomplete export and production volume data, for products with volume data aggregate shipments were fairly constant over the decade, though there were some winners and losers over the period. The main decrease in volume of exports to the U.S. was coated paper shipments. These volume decreases were largely offset by increased sanitary paper and packaging product shipments. Looking at Canadian exports in U.S. dollars paints a better picture than Canadian export data reported in Canadian dollars. If exports are measured in U.S. dollars, the value of Canadian shipments to the United States held steady, even throughout the recession. So despite the turbulent conditions of the 2000s the converted paper industry held up reasonably well, the lone bright spot over the period. However, it is difficult to herald this as a success since compared to other countries, Canada lost market share during the period, despite its close proximity to the U.S. market. New and old market competitor nations such as China, Vietnam, Mexico and Germany all made considerable gains in the U.S. market over the decade, shrinking Canadian market share.

Foreign demand for Canadian pulp followed a similar, albeit gentler, downward trend to paper exports. Between 2000 and 2009 Canadian pulp export volumes decreased or remained unchanged, depending on grade. The biggest drop in export volumes occurred with Northern Bleached Softwood Kraft (NBSK). Between 2000 and 2009 exports fell over 3 million tonnes per year; granted; half of this decline occurred during the 2007-2009 global recession. On a positive note, exports of chemi-thermomechanical pulp increased slightly over the decade as did dissolving pulp.

Unlike paper trends, the biggest regional decline for Canadian pulp exports between 2000 and 2009 occurred in Western Europe due to rising domestic capacity. The biggest drop in demand was for NBSK pulp in Germany, Belgium, France, and the UK. BC, being the largest supply region to the European market, lost 1.4 million tonnes of demand or roughly the output of four mills. The next biggest declines occurred in U.S. markets, especially the U.S. Northeast region. The lost demand in this market greatly affected Atlantic Canada. Also, there were significant declines in exports to Japan and South Korea. Offsetting some of the declines in demand in Europe, U.S., and Japan were increased exports to China, India, Mexico, Australia, Turkey, and Saudi Arabia. The pulp shipped to these markets differed with China importing all pulp types, Mexico importing NBSK, India importing bleached hardwood Kraft, and the western Asian countries importing mainly chemi-thermomechanical pulps. By far the largest increase in exports was to China, which greatly compensated Western Canadian producers for lost exports to other markets.

\section{Looking Ahead}

Despite significant reductions during the 2000s, the Canadian pulp and paper sector remains a significant manufacturing sector in Canada. In 2012 the sector accounted for 3.9\% of Canadian manufacturing employment, $4.2 \%$ of manufacturing shipments, and $0.4 \%$ of Canada's gross domestic product (Statistics Canada n.d. [a],[b],[c]). Regionally, its importance varies depending on the provinces economic structure and the size of the industry (Fig. 7).

The paper industry seems to have found some stability since the end of recession but many indicators point to a continued, albeit slower, decline in the industry (Fig. 3 to Fig. 5). Looking back in time, the industry went through a period of stagnation between the mid-1970s and mid-1980s before taking off on an exceptional growth period through the 1990s. However, the North American economy is significantly different now than then and it is not clear if history will repeat itself. The digitization of personal and business communications, the wide-scale adoption of environmental policies that favour reduced consumption of paper by consumers and businesses, and the shift of many forms of manufacturing to developing regions, and thus packaging demand, are all trends that are likely to continue. The increased use of recovered paper and hardwood pulp will also likely continue for the foreseeable future, tempering demand for Canada's pulp. Of course, unexpected increases in paper demand, such as halt in the shift from printing and writing paper to digital formats for some publications, or big jumps in overseas demand due to structural changes in developing economies, could reverse the trends and help stabilize the sector. Given this uncertain future it is important for the rest of the forest sector to hedge against a negative future for the paper sector.

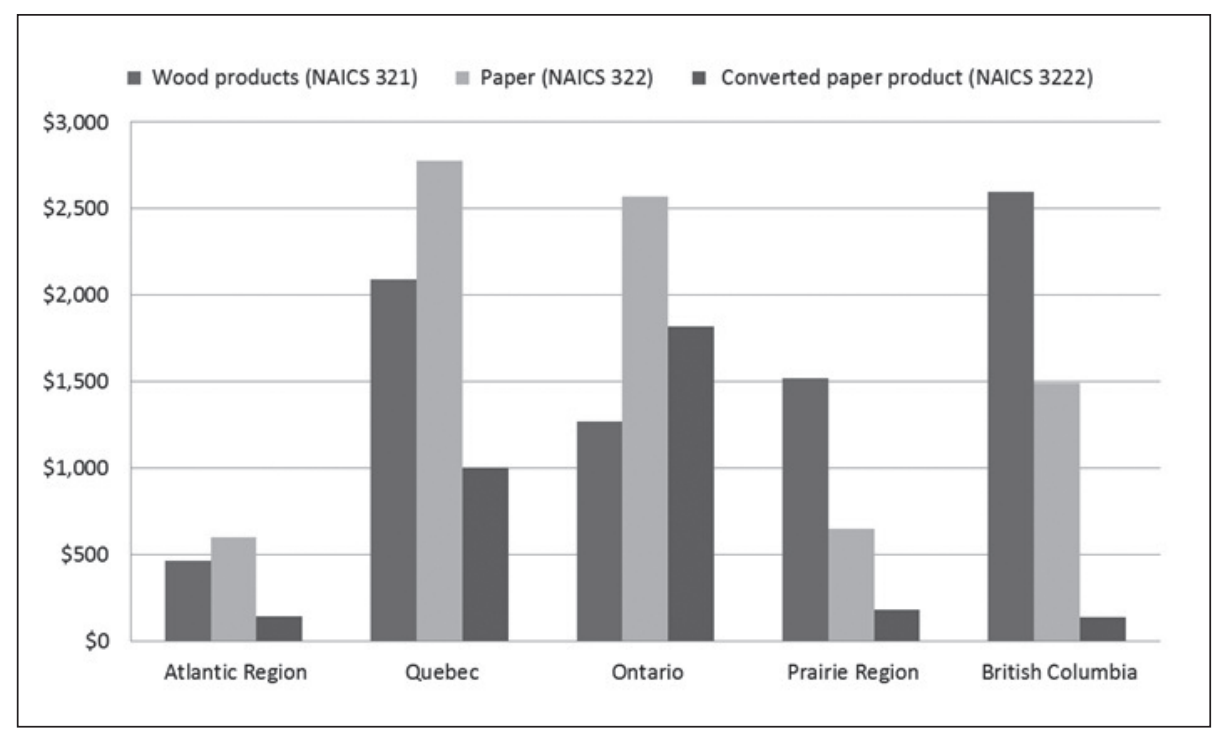

Fig. 7. Regional paper industry, converted paper sub-sector, and solid wood industry revenues, 2010. Source: Statistics Canada n.d. [g] 
The pulp and paper sector is interconnected to the solid wood, logging, and forestry sectors of the Canadian forest economy through its purchases of roundwood and wood chips and other wood fibre and the existence of integrated forestry companies. In 2007 the pulp and paper industries purchased approximately $\$ 1$ billion worth of pulpwood from the forestry and logging industry and $\$ 2.3$ billion worth of wood chips and other wood fibre from the wood products industries (Statistics Canada n.d. [f]). The purchases represent about $8 \%$ and $7 \%$ of the forestry and wood products industries total output, respectively (Statistics Canada n.d. [f]). According to data provided by Fisher International (n.d.), in 2013 Canadian paper and pulp mills sourced about $20 \%$ of their wood fibre directly from the logging industry in the form of pulpwood and about $71 \%$ in the form of wood chips from sawmills and chip mills, and the remaining fibre from recovered paper products. The volume of chips and pulpwood consumed by the current group of mills is approximately 40 million oven-dry tonnes of biomass. Of the volume of virgin fibre consumed, $68 \%$ was consumed in pulp facilities geared to pulp markets while $22 \%$ was consumed in graphic paper mills of one type or another. The packaging and tissue and towel mills consume the greatest amount of recycled fibre and are thus the least tied to the other forest industries. Assuming the graphic papers mills are the most vulnerable to continued declines in North American market demand, the regional industries in Quebec are at greatest risk, where graphic paper mills consume over $50 \%$ of the total virgin fibre sourced by the paper industries from the logging and solid wood product industries. The next vulnerable regions are Ontario and the Maritimes, with 25\% and 21\% of virgin fibre consumed in graphic paper mills.

While it is very unlikely that all of the graphic paper mills in Canada will disappear over the next 10 or 15 years, it is likely some will close, either because of reduced North American demand or rationalization of mill capacity to the most efficient mills. In order to mitigate some of the negative impacts from continued decline in traditional paper industries companies and governments can remain committed to the development of new wood, fibre, and energy products and manufacturing processes through research and development. Research and development has been instrumental in the continuous development of the industry throughout its history (Snider 1990). While R\&D may help mitigate future downside risks to the industry it may not allow each firm to adapt to changing markets. As such, it is perhaps realistic for all vested stakeholders to plan for the possibility of some additional capacity reductions, in particular in mechanical graphic papers.

\section{Conclusions}

In summary, the Canadian wood paper industry developed from its early beginnings in the 1860 s to a superpower in pulp and mechanical paper production over much of the $20^{\text {th }}$ century. This development was primarily due to rapid expansion of U.S. demand for newsprint and its natural advantage in producing pulp, namely mechanical and sulphite pulps, due to abundant timber and water resources. The increased adoption of Kraft pulping and new hybrid mechanical pulps expanded the scope of products and markets for the Canadian paper sector. However, these same technologies led to expansion of the paper industry in other regions of North America and the world. While total paper consumption in the U.S. increased greatly over the period, with the exception of mechanical papers, $\mathrm{Ca}$ nadian industry was not able to become a major supplier of many other paper products. In addition, the broad adoption of the environmental policies to reduce, reuse and recycle and the increased digitization of communications media over the past 20 years in North America added further challenges for the Canadian paper sector greatly dependent on this market. These trends are likely to continue and it is prudent the entire forest industry prepare for such a future.

\section{References}

[CPPA] Canadian Pulp and Paper Association. 1966. Reference Tables. Montreal, QC. 32 p.

. 1979. Reference Tables. Montreal, QC. $40 \mathrm{p}$.

.1986. Reference Tables. Montreal, QC. 42 p.

1999. Reference Tables. Montreal, QC. 58 p.

Christie. D. 2004. Looking west: historical overview of the industry in BC. Pulp and Paper Canada. Available at http://www. pulpandpapercanada.com/news/looking-west-historical-overview-ofthe-industry-in-bc/1000141957/ [Accessed July 30, 2010].

Diesen, M. 1998. Economics of the pulp and paper industry. Fapet $\mathrm{Oy}$, Finland. $186 \mathrm{p}$.

Dominion Bureau of Statistics. 1930. The Canada Year Book. Ottawa, Canada. Available at http://www65.statcan.gc.ca/acyb_r000eng.htm [Accessed February 15, 2013].

1945. The Canada Year Book. Ottawa, Canada. Available at http://www65.statcan.gc.ca/acyb_r000-eng.htm [Accessed February $15,2013]$.

[FAO] Food And Agriculture Organization of the United Nations. n.d. FAOSTAT Forestry database. Available at http://faostat.fao.org/ site/630/default.aspx [Accessed October 20, 2013].

Fisher International. n.d. FisherSolve database (Electronic database). South Norwalk, CT.

Hetemäki, L. 2010. Information and Communication Technology. In G. Mery, P. Katila, G. Galloway, R.I. Alfaro, M. Kanninen, M. Lobovikov and J. Varjo (eds.). 2010. Forests and Society - Responding to Global Drivers of Change. pp. 159-165. IUFRO World Series Volume 25. Vienna. 509 p. Available at http://www.metla.fi/pp/LHet/hetemaki_ICT.pdf [Accessed August 12, 2013].

Howard, J.L. 2007. U.S. timber production, trade, consumption, and price statistics 1965-2005. Research Paper FPL-RP-637. U.S. Department of Agriculture, Forest Service, Forest Products Laboratory, Madison, WI. $91 \mathrm{p}$.

Jaakko Pöyry. 1995. World paper markets up to 2010. Jaakko Pöyry Consulting Oy, Helsinki. 153 p.

[NRCan] Natural Resources Canada. 2001. Selected forestry statistics Canada: Special edition - Historical series. Industry, Economics and Programs Branch, Canadian Forest Service, Ottawa.

Paperloop.com. 2000. Pulp and paper North American factbook 2000. Paperloop.com, San Francisco, California. 442 p.

[PPPC] Pulp and Paper Products Council. 2008a. Newsprint data 2008. (Digital copy). Pulp and Paper Products Council. Montreal, QC. $32 \mathrm{p}$.

. 2008b. Wood pulp data 2008. (Digital copy). Pulp and Paper Products Council. Montreal, QC. 32 p.

Roach, T.R. 1994. Newsprint: Canadian supply and American demand. Forest History Society, Durham, NC. 56 p.

Shipley, J.W. 1929. Pulp and paper making in Canada. Longmans, Green and Company. Toronto, ON. 139 p.

Snider, E.H. 1990. Canadian accomplishments in pulp and paper research 1905-1990. The Forestry Chronicle 66(2): 156-164. 
Statistics Canada. 1983. Historical Statistics of Canada. Available at http://www.statcan.gc.ca/pub/11-516-x/11-516-x1983001-eng.htm [Accessed January 10, 2013].

. n.d. [a] Table no, 281-0023. Employment (SEPH). CANSIM (database). [Accessed November 19, 2013].

. n.d. [b] Table no. 304-0014. Manufacturers' sales, inventories, orders and inventory to sales ratios. CANSIM (database). [Accessed November 19, 2013].

- n.d. [c] Table no. 379-0027. Gross domestic product (GDP) at basic prices. CANSIM (database). [Accessed November 19, 2013]. Statistics Canada n.d. [d] Table no. 031-0002 . Flows and Stocks of fixed non-residential capital. CANSIM(database). (accessed November 19, 2013).

- n.d. [e]. Canadian International Merchandise Trade Database and Canadian International Merchandise Trade Database. Available at http://cansim2.statcan.gc.ca/cgi-win/CNSMCGI.PGM?Lang $=$ E\&CIMT_Action $=$ Sections\&ResultTemplate $=\mathrm{C}$ II CIMT5 [Accessed December 11, 2013].

. n.d. [f]. Table no. 381-0009 Inputs and outputs, by industry and commodity, L-level aggregation and North American Industry Classification. CANSIM (database). [Accessed November 19, 2013].

Statistics Canada n.d. [g]. Table no. 301-0006 Principal statistics for manufacturing industries by North American Industry Classification. CANSIM (database). [Accessed September 12, 2014].
Toivanen, H. 2004. Learning and Corporate Strategy: The Dynamic Evolution of the North American Pulp and Paper Industry, 1860-1960. Ph.D. Dissertation, Georgia Institute of Technology. p. 341.

U.S. Census. n.d. Manufacturers' shipments, inventories, and orders. Available at http://www.census.gov/manufacturing/m3/ [Accessed March 8, 2013].

[U.S. ITC] International Trade Commission. n.d. Available at http://dataweb.usitc.gov/ [Accessed March 8, 2013].

Wallace, W.S. (ed.). 1949. The Encyclopedia of Canada. Newfoundland supplement. University Associates of Canada. Toronto. 104 p.

Wellwood, R.W. 1960. The utilization of spruce in Canada. The Forestry Chronicle 36(2): 125-135.

Woodbridge, Reed and Associates. 1988. Canada's forest industry the next twenty years: prospects and priorities - pulp and paper. Report prepared for Canadian Forest Service, Industry, Trade and Technology Directorate, Economics Branch, Ottawa. 362 p. 